\title{
$\mathrm{KaKa}$

\section{Pengaruh Sholat Tahajud Terhadap ESQ (Emotional Spiritual Quotient) Santri}

\author{
N ur H afiah ${ }^{1}$, M uchammad Saiful M achfud ${ }^{2}$ \\ IAI Darussalam Blokagung Banyuwangi ${ }^{12}$ \\ Email: nurhafifah@iaida.ac.id ${ }^{1}$, saifulmachfud@gmail.com ${ }^{2}$
}

\begin{abstract}
ABSTRAK
Sholat tahajud merupakan sholat sunah yang paling utama kedudukannya setelah sholat fardhu, pada prosesnya selur uh santri asrama A I H ikmah sejak awal mereka masuk di asrama langsung di ajarkan untuk melaksanakan sholat tahajud. ESQ memiliki peran yang sangat penting bagi seseorang dalam proses mereka ber interaksi antara sesama manusia dan manusia dengan Alloh. Asrama Al Hikmah yang dihuni banyak santri dengan bercama-macam karakter dan wataknya harus memiliki ESQ yang tinggi agar dalam kesehariannya mereka menjaga hubungan antara sesama manusia dan Alloh. D alam penelitian ini diarahkan pada pengaruh salat tahajud terhadap ESQ (Emotional Spiritual Quotient) Santri Putra Asrama Al-Hikmah Pondok Pesantren Darussalam Blokagung Banyuwangi. Jenis penelitian ini menggunakan metode penelitian kuantitatif dengan teknik statistik regresi sederhana. Populai penelitian ini adalah seluruh santri asrama Al Hikmah yang masih aktif di asr ama yang berjumlah 300 santri, dengan sample 75 santri yang di ambil secara acak. peneliti menemukan bahwa Terdapat pengaruh yang singnifikan antara sholat tahajud terhadap ESQ (Emosional Spiritual Quotient) santri. D iperoleh nilai N $=75$ dan diuji signifikan menggunakan uji regresi sederhana menghasilakan. D engan demikian dapat ditarik kesimpulan bahwa menerima $\mathrm{Ha}$ dan menolak $\mathrm{Ho}$, artinya bahwa Terdapat pengaruh yang singnifikan antara sholat tahajud terhadapESQ (Emosional Spiritual Quotient) santri.
\end{abstract}

\section{Kata Kunci : Sholat T ahajud, E SQ (E motional Spiritual Q uotient) Santri}

\begin{abstract}
The midnight prayer is a sunnah prayer which has the most important position after the fardhu prayer, in the process all students of the AI H ikmah dormitory from the beginning they entered the dormitory were immediately taught to carry out the midnight prayer. ESQ has a very important role for someone in their process of interacting between fellow humans and humans with Allah. The AI Hikmah dormitory, which is inhabited by many students with various characters, must havea high ESQ so that in their daily lives they maintain the relationship between fellow humans and Allah. In this study, it was directed at the effect of the midnight prayer on the ESQ (Emotional Spiritual Quotient) of the Santri Putra Al-Hikmah Boarding School at Darussalam Blokagung Banyuwangi Islamic Boarding School. This type of research uses quantitative research methods with simple regression statistical techniques. The population of this study were all students of the AI Hikmah dormitory who were still active in the dor mitory, amounting to 300 students, with a sample of 75 students who weretaken randomly. The researcher found that there was a significant influence between the midnight prayer on the ESQ (E motional Spiritual Quotient) of the santri. 0 btained value $\mathrm{N}=75$ and tested significant using simple regression test results. Thus it can be concluded that accepting $\mathrm{Ha}$ and rejecting $\mathrm{Ho}$ means that ther e is a significant influence between the midnight prayer on the ESQ (Emotional Spiritual Quotient) of the santri.
\end{abstract}

Keywords: Tahajud Prayer, ESQ (Emotional Spiritual Quotient) of Santri 


\section{A. PENDAHU LUAN}

Ibadah merupakan tindakan ritual yang berdasarkan syariat, ibadah berarti pengabdi. Makna ini seakar dengan kata 'abd yang berarti hamba atau budak. Dalam hal ini adalah penghambaan dan pengabdian diri kepada Allah SW T. (Muhammad Sholihin, 2011:15)

Ibadah merupakan upaya mendekatkan diri kepada Allah SW T. Allah SW T adalah Dzat Yang $M$ aha Suci dan $M$ aha segala-galaN ya yang tidak dapat di dekati kecuali orang yang suci. Para ulama' dan pakar islam mengakui, bahwa salah satu ibadah yang sangat penting dalam islam adalah Sholat. Sholat, memiliki kedudukan istimewa baik di lihat dari cara memperoleh perintahN ya yang dilakukan secara langsung.

Sholat di ambil dari bahasa Arab yang memiliki arti do'a. Sedangkan, menurut istilah, sholat bermakna serangkaian kegiatan ibadah khusus atau tertentu yang dimulai dengan takbiratul ikhram dan di akhiri dengan salam. Pengertian itu mengindikasi bahwa perwujudan dari pola kesadaran akan kehadiran Allah dalam hidup manusia, harus juga bermanifestikan dalam bentuk ibadah secara simbolik.

Selain sholat fardhu yang wajib kita kerjakan ada banyak juga sholat-sholat sunah yang bisa kerjakan guna untuk sarana kita lebih mendekatkan diri kepada Allah SW T.

Diantaranya sholat sunnah yang pernah dilakukan oleh nabi Muhammad yaitu sholat tahajud. Sholat tahajud dikerjakan di sepertiga malam dengan jumlah raka'at sebanyak dua belas dan enam kali salam.

Sholat tahajud adalah sholat sunah yang utama. Kedudukannya setelah sholat wajib.hukummnya sunnah muakkad. Tahajud ini sholat sunnah yang paling utama. (Muhammad Khatib, 2013:9)

Tahajud artinya aktivitas bangun di waktu malam untuk mengerjakan sholat. Sedangkan mutahajjud adalah orang yang bangun malam untuk melaksanakan sholat. (Herliawan Setiabudi, 2016:176) Kemudian terlepas dari hikum wajib dan sunahnya melaksanakan sholat tahajud, peneliti tidak akan membahas 
tersebut akan tetapi penulis mencoba meneliti pengaruh sholat tahajud terhadap kecerdasan emosional dan spiritual atau Emotional and Spiritual Quotion (ESQ). ESQ merupakan gabungan dari pada EQ (emotional Quotient) dan SQ (Spiritual Quotient).

Kecerdasan emosi adalah kemampuan merasakan, memahami secara efektif, menerapkan daya dan kepekaan emosi sebagai sumber energi, informasi, koneksi dan pengaruh manusia. (Ary Ginanjar Agustin, ,2001: 285)

Kecerdasan spiritual adalah kemampuan untuk memberi makna spiritual terhadap pemikiran, perilaku dan kegiatan, serta mampu menyinergikan IQ, EQ, SQ secara komperehensif. (Ary Ginanjar Agustin, ,2001: 285)

Selama ini kecerdasan senantiasa dikonotasikan dengan kecerdasan intelektual atau yang sering dikenal sebagai intelligence Quotient. N amun saat ini, anggapan bahwa kecerdasan manusia hanya tertumpu pada dimensi intelektual saja sudah tidak berlaku lagi. Selain IQ, manusia juga masih memiliki dimensi kecerdasan lainnya, yaitu kecerdasan emosi (emotional Q uotient) dan kecerdasan spritual (Spiritual Quotient) atau biasa disebut dengan ESQ (E motional Spiritual Quotient).

Secara sadar atau tidak sadar, perkembangan emosi dan rohani yang tidak seimbang menyebabkan terjadinya masalah dan kegagalan manusia mencari jawaban kepada apa yang diperlakukan dalam hidup. ESQ juga sebenarnya sangat amat berkaitan dengan pembangunan modal insan yang membentuk pribadi manusia yang baik dan masyarakat harus dilatih supaya emosi dan rohani dapat berkembang dengan seimbang.

Ary

Ginanjar mengungkapkan sholat adalah anugerah terbesar dari Allah kepada umat manusia, kepada siapa saja yang dengan rendah hati melakukannya. Shalat, berfungsi seb agai metode pengulangan, dimana potensi spiritual yang berisikan elemen-elemen karakter atau sifatsifat dan agung itu diasah dan diulang-ulang, sehingga akan terjadi proses behaviorisme yang mengaruh pada internalisasi karakter. (Ary Ginanjar, 2003: 277. 
Sholat tahajud merupakan sholat sunnah yang paling utama, kedudukannya setelah sholat fardhu. (Sayyid Bakri Syatha, 2017: 276 ). Dalam pelaksanannya sholat tahajud dikerjakan pada waktu malam hari dengan syarat harus terlebih dahulu walaupun hanya sebentar. Di waktu malam adalah waktu yang tepat dimana orang lain terlelap dalam tidurya sedangkan kita bangun untuk mengerjakan sholat dan bermunajat kepada Allah.

Dalam kesunyian malam kita bisa melatih, mengontrol, menenangkan diri kita, menganganangan segala macam hal yang sudah kita perbuat selama ini. Bisa jauh lebih mengenal diri kita akan kekurangan-keurangan yang kita miliki akan hal-hal yang perlu kita benahi agar kita menjadi pribadi yang lebih baik.

U stadz Yazid al-Basthomi, LC mengutip pendapat Imam Ghazali yang menetapakan bahwa hukum mengenal diri sendiri adalah fardhu 'ain. Yang sesuai dengan hadist Rosululloh SAW yang mengatakan

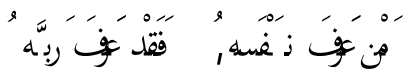

"Barang siapa mengenal dirinya, maka pasti mengenal Tuhannya". (Yazid alBasthomi, 2016: 14)

Menurut Abdul Kamal, "Seseorang bisa mencapai tingkatan yang mulia dengan mendekatkan diri secara benar kepada Allah SWT. Disamping memiliki keimanan yang sempurna. Tingk atan yang tinggi ini hanya dapat diraih dengan ketaatan dan ibadah-ibadah sunnah dalam shalat, puasa, jihad, sedekah dan sebagainya. Di antara ibadah-ibadah sunah itu adalah shalat tahajud, yaitu sholat yang jauh dari pandangan manusia tetapi dekat kepada Allah. Itulah sebabnya Allah menegaskan dalam QS. al-M uzamil ayat 6:

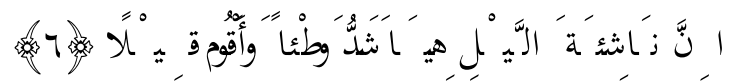

"Sesungguhnya bangun di waktu malam adalah lebih tepat (untuk khusyuk) dan bacaan di waktu itu lebih berkesan ".

$\mathrm{H}$ al tersebut senada dengan fenomena di atas ditemukan oleh peneliti di lapangan yaitu di asrama Al-Hikmah Pondok Pesantren Darussalam Blokagung Banyuwangi. Dalam kesehariannya para santri selain melaksanakan kegiatan sholat berjamaah, diniyah, sekolah 
kurikulum dan lain sebagainya. Para santri seusai menjalankan kegiatan sekolah diniyah mereka diberikan waktu untuk tidur sebentar yang kemudian nanti dibangunkan guna untuk melaksanakan shalat tahajud.

Dalam prosesnya semua pengurus bekerja sama dalam membangunkan para santri agar mereka melaksanakan shalat tahajud, hal ini bertujuan agar para santri terbiasa menlaksanakan shalat tahajud. Namun masih ada pula santri yang tidak mau melaksankan shalat tahajud dengan berbagai alasan. Padahal para santri yang dibangunkan dan diajak untuk sholat tahajud tidak mau mereka tidak langsung tidur akan tetapi masih bermain dengan teantemannya kebanyakan mereka yang masih sekolah pada tingkat SLTP. Lain lagi dengan santri yang sudah agak dewasa, kalaupun mereka tidak ikut sholat tahajud yang dilaksanakan di asrama mereka akan sholat sendiri.

Santri yang menempati asrama Al Hikmahpun berasal dari berbagai wilayah di Indonesia yang mempunyai karakteristik yang bermacam-macam dan tentunya berbeda pula. Sehingga dibutuhkan kecerdasan emosional spiritual agar dalam kesehariannya para santri satu sama lain mampu dan bisa hidup bersosial dengan teman sekamar maupun teman seasrama yang mempunyai karakter, sifat dan watak yang berbeda-beda sehingga, nantinya tidak menimbulkan perselisihan dan hal-hal yang tidak diinginkan yang dapat merusak hubungan sesama santri.

Peneliti lebih memilih shalat tahajjud dalam penelitiannya, tidak memilih shalat-shalat sunah yang lain yang sudah dibiasakan oleh santri asrama Al-Hikmah Pondok Pesantren Darussalam Blokagung Banyuwangi karena beberapa alasan yaitu secara emosional dan spiritual shalat tahajjud mempunyai kenikmatan tersendiri yang tidak dapat dirasakan pada shalat sunah lainnya. Pertama, dilaksanakan setelah tidur sehingga tubuh berada dalam keadaan fresh (segar) dan fikiran berada dalam keadaan rileks (tenang). Kedua, tidak ada gangguan berat, yang bisa terjadi sebab orangorang disekitar sedang terlelap yang ada hanyalah kita dan tuhan. Ketiga, dilaksanakan dalam waktu yang 
cukup panjang dan

berkesinambungan

sehingga

memungkinkan

terjadinya

konsentrasi dan kontempasi yang

cukup Intens. (Ary Ginanjar,2001:212)

Adapun rumusan masalah

dalam penelitian ini yaitu Bagaimana

pengaruh sholat tahajud terhadap

ESQ (Emotional Spiritual Quotient)

Santri Putra Asrama Al-Hikmah

Pondok Pesantren Darussalam

Blokagung Banyuwangi ?

Tujuan penelitian dalam

penelitian ini adalah Untuk

mengetahui adakah pengaruh sholat

tahajud ESQ (Emotional Spiritual

Quotient) Santri Putra Asrama Al-

Hikmah Pondok Pesantren

Darussalam Blokagung Banyu wangi".

\section{B. KAJIIAN PUSTAKA}

1 Sholat Tahajud

Secara bahasa tahajud yaitu بالتكلف رفع yang artinya bangun tidurdengan berat, sehingga syarat melaksanakan sholat tahajud menurut mayoritas Ulama harus tidur terlebih dahulu. Sedangkan tahajud secara istilah adalah sholat sunah yang dilakukan pada malam hari setelah melaksanakan sholat isya' dan setelah bangun tidur. (Sheikh Zaynuddin Al Malibari, 2017:50)

Kata tahajud merupakan gabungan dari ta dan al-hajud. Ta merupakan akronim dari tayaqush yang berarti "terjaga dari tidur". Sementara al-hajud berrti "tidur". Karena, bila sholat tahajud di kerjakan sebelum tidur maka tidak dinamakan lagi sholat tahajud melainkan hanya sholat malam biasa seperti halnya sholat sunah-sunah lainnya. (Sayyid Bakri Syatha, 2017: 276)

Sholat tahajud adalah sholat yang dikerjakan sedikitnya dua raka'at dan sebanyak-banyaknya tidak terbatas, waktu mulainya dikerjakan pada malam hari waktu isya' sampai terbitnya fajar. Sholat malam bisa disebut sholat tahajud, tetapi dengan syarat harus tidur terlebih dahulu, meskipun tidurnya itu hanya sebentar saja. Hukum melaksanakan sholat tahajud adalah sunah mu'akkad yaitu sunah yang sangat dianjurkan untuk dikerjakan. Oleh karena itu, Nabi Muhammad SAW sangat menganjurkan kepada umatnya untuk senantiasa mengerjakan sholat tahajud. 


\section{$\mathrm{TaKa}$ \\ Jurnal Komunikasi dan Konseling Islam \\ Volume I, Nomor 1, Januari 2021}

Sholat Tahajud bisa disebut qiyamul lail,namun sebenarnya ada perbedaan yang cukup signifikan antara kedua istilah itu. Disebut sholat tahajud apabila sholat itu dilakukan setelah tidur. Sedangkan qiyamul lail tidak harus didahului dengan tidur yang dilakukan sebelumnya.

Banyak anjuran untuk melaksanakan sholat tahajud. Allah berjanji kepada hambanya yang mau mengerjakan sholat tahajud, Allah ak an memberi imbalan dan ganjaran yang sangat besar di dunia maupun di akhirat.

Diantara

menerangkan sholat tahajud terdapat dalam Q.S. al-M uzammil:1-

7.

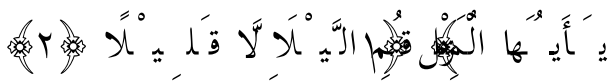

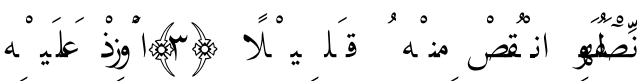

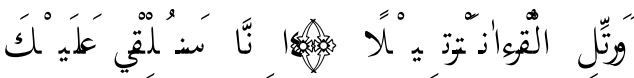

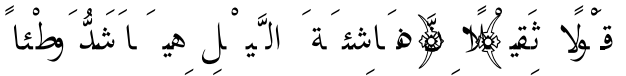

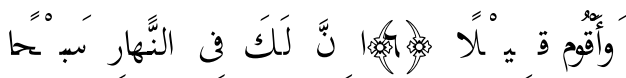

$$
\begin{aligned}
& \text { طَويْ }
\end{aligned}
$$

Artinya : "Hai orang-orang yaang berselimut! Bangunlah malam hari untuk mendirikan sholat, sepanjang malam kurang sedikit, yaitu di tengah malam, atau kurang dari itu, atau lebih dari setengah malam itu, Bacalah alQur'an dengan penuh perhatian. Sesungguhnya kami akan mewahyukan al-Qur'an kepadamu berupa perkataan yang mengandug peristiwa. Sesungguhnya beribadah waktu malam itu lebih bagus, dan bacaan waktu itu lebih berkesan. Di siang hari kamu sunguhsungguh banyak urusan".

Serta di jelaskan dalam Q.S alInsan: 26.

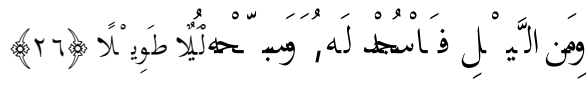

Artinya : "D an pada sebagian malam, maka sujudlah kepada-N ya dan bertasbihlah kepada- $N$ ya pada bagian yang panjang di malam hari".

Adapun sholat tahajud merupakan sholat paling utama setelah slat wajib. Begitu banyak keutamaan sebagaimana disebutkan di dalam Q.S. al-Isra':79.

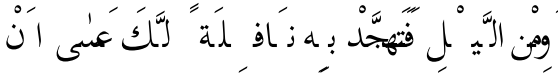

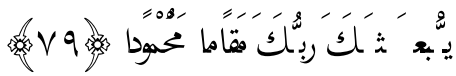

Artinya : "D an pada sebagian malam hari bersholatlah tahajudlah 


\section{$\mathrm{KaKa}$ \\ Jurnal Komunikasi dan Konseling Islam \\ Volume I, Nomor 1, Januari 2021}

kamu suatu ibadah tambahan bagimu, mudah-mudahan Rabb-mu mengangkat ke tempat yang terpuji".

Ketika seseorang berkhalwat di tengah malam. Ia akan merasakan dirinya sendirian menghadap Allah. la merasa kecil di hadapanNya sehingga minta dalam mengagunggkan kebesaran $\mathrm{N}$ ya, saat itulah ia akan merasakan adanya "penyatuan" antara dirinya dengan Tuhannya. Batinnya (jiwanya) akan bermi'raj (naik) menghadap sang Kholiq untuk menyampaikan tujuannya. Itulah sebabnya, sholat malam memiliki arti penting bagi setiap orang yang menjalankannya. Shohabat Ali bin Abi Thalib dikenal orang yang tekun mengerjakan sholat malam. Beliau menganggap tahajud adalah kendaraan malam yang mengantarkan ke tempat tujuan.

Saat mengalami goncangan jiwa karena beratnya persoalan hidup, mereka dihadapkan pada suatu pilihan yang berat dan mengandung resiko yang tinggi terhadap keselamatan perusahaan, organisasi atau pemerintahan, maka cenderung ak an menyelamatkan diri sendiri dan mengorbankan lembaga yang dipimpinya. Karena itu mereka mutlak berkewajiban memiliki kemampuan mengenali dan memahami ESQ. (Ary Ginanjar Agustin, 2001: 285)

Melalui sholat tahajud yang dilaksankan pada malam hari dalam keadaan sunyi merupakan salah satu metode bentuk dalam upaya mengenal dan memahami ESQ .

W aktu melaksanakan sholat sunah tahajud terbagi menjadi 3 waktu (Sheikh Zaynuddin Al Malibari, 2017:51), yaitu :

1. Waktu yang utama untuk melaksanakan sholat tahajud adalah pada sepertiga malam yang pertama atau sekitar pukul 19.00 hingga pukul 22.00 .

2. Waktu yang lebih utama melaksanakan sholat tahajud adalah pada sepertiga malam yang kedua atau sekitar 22.00 hingga pukul 0100 dini hari.

3. Dan waktu yang paling utama untuk melaksanakan sholat tahajud adalah pada sepertiga malam yang ketiga (sepertiga malam yang terakhir) atau sekitar pukul 0100 dini hari 
hingga masuknya sholat fardhu yaitu sholat subuh.

Untuk melaksanakan sholat tahajud. Langkah-langkah yang harus dilakukan adalah :

a. M engucapkan niat sholat tahajud pelan dan menghayati artinya dalam hati. Adapun niat sholat tahajud adalah sebagai berikut :

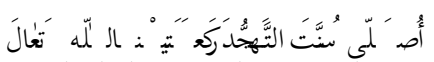

Artinya : "Aku (berniat) sholat tahajud dua raka'at karena Allah Ta'ala".

Ini adalah sebuah awal aktivitas kita, ketika akan memulai ibadah sholat, niat merupakan visi ke depan.

b. Mengucapkan takbir (آكّبَ sambil mengangkat kedua tangan ke atas seperti takbir sholat biasanya.

c. Membaca do'a iftitah. Karena sifatnya sunah, akan lebih baik apabila dilakukan .

d. Membaca surat Al-Fatihah.

Al Fatihah, surat pertama dalam Al Qur'an ini merupakan pembuka sonic dunia batin, secara mistis merangkum isi Al Qur'an ke dalam 7 ayat. Al Fatihah merupakan metode evaluasi diri, membandingkan idealisme Al Fatihah dengan realitas diri. (Moh. Sholeh, 2012, :272.)

e. Membaca surat pendek seperti An-Nas, Al-Ikhlas, Al-Falaq, atau surat lainnya dalam AlQur'an.

f. Melakukan gerakan ruku', i'tidal, sujud, hingga salam sambil membaca bacaan untuk gerak an tersebut.

g. Untuk raka'at selanjutnya, ikuti langk ah $b$-f.

h. Setelah salam, anda di sunahkan membaca wirid, tasbih, tahmid, takbir, sholawat, istighfar dan do'a sholat tahajud.

i. Do'a sholat tahajud

Sholat tahajud merupakan macam-macam sholat sunah yanag sangat dianjurkan pelaksanaannya, karena sholat sunah ini memiliki berbagai keutamaan sholat tahajud serta keistimewaannya, seperti :

Sholat tahajud dapat mengangkat drajat manusia.

$M$ anfaat sholat tahajud bagi yang mendirikannya, merupakan suatu ibadah tambahan yang dapat mengangkat drajat untuk setiap umat muslim. 
Sholat tahajud untuk berdo'a kepada Allah SWT. Sholat sunah tahajud menjadi sholat dimana do'a mustajab agar keinginan tercapai dengan do'a secara khusyu' karena Allah SWT telah menjanjikan terkabulnya do'a-do'a umat-Nya di waktu tersebut.

Orang yang sholat tahajud akan memperoleh macam-macam nikmat yang menyejukkan pandangan mata.

Dihapuskan segala dosa dan kejelekannya dan terhindar dari penyakit.

Sholat sunah tahajud merupakan pelengkap bagi sholat fardhu.

Sholat sunah tahajud merupakan cara sarana metode atau jalan untuk mendekatkan diri kepada Allah SW T. Hidup dekat dengan Allah adalah tujuan utama. Karena dekat dengan Allah adalah keadaan yang tidak pernah membuat kita jemu berada dekat di sisiNya. $\mathrm{Hal}$ ini senada dengan Ary Ginanjar dalam ESQ nya dimana dalam ESQ tujuan intinya adalah lebih memahami diri sendiri dan lebih mendekatkan diri kepada Allah SW T.

2. ESQ (Emosional Spiritual Quotient)
Dalam kamus besar Bahasa Indonesia emosional memiliki arti menyentuh perasaan, mengharukan, dengan emosi, beremosi dan penuh emosi. Spiritual memiliki arti berhubungan dengan atau bersifat kejiwaan (rohani dan batin). Cerdas memiliki arti perkembangan akal budi (untuk berfikir, mengerti dsb), tajam pikiran.

Kecerdasan emosi adalah kemampuan merasakan, memahami secara efektif, menerapkan daya dan kepekaan emosi sebagai sumber energi, informasi, koneksi dan pengaruh manusia. (Ary Ginanjar Agustin, 2001: 285)

Danah Zohar dan Ian $M$ arshall mendefinisikan kecerdasan spiritual sebagai kecerdasan untuk menghadapi persoalan makna atau value, yaitu kecerdasan untuk menempatkan perilaku dan hidup kita dalam konteks makna yang lebih luas dan kaya, kecerdasan untuk menilai bahwa tindakan atau jalan hidup seseorang lebih bermakna dibandingkan dengan yang lain. (Ary Ginanjar Agustin, 2001: 285)

M enurut Ary Ginanjar ESQ merupakan energi dua pemikiran 
yaitu hubungan manusia dengan manusia (EQ) dan manusia dengan tuhannya (SQ). Meski keduanya berbeda, ternyata EQ dan SQ memiliki muatan yang sama pentingnya untuk dapat bersinergi antara satu sama lain. (Ary Ginanjar Agustin, 2001:12)

ESQ merupakan singkatan dari Emotional Spiritual Quotient yang merupakan gabungan Emotional Quotient (EQ) dan Spiritual Quotien (SQ), yaitu Penggabungan antara pengendalian kecerdasan emosi dan spiritual agar mencapai keseimbangan Horizontal (manusia dengan manusia) dan Vertikal (manusia dengan Tuhan) demi tercapainya kehidupan yang bahagia di dunia dan akhirat.

Oleh sebab itu, ESQ sangat berperan penting dalam kehidupan sehari-hari seseorang, dengan adanya ESQ seseorang mampu mengatur, mengolah, memahami situasi dan kondisinya. Karena manusia adalah mahkluk sosial yang dimana membutuhkan bantuan orang lain. Oleh karena itu, manusia harus bisa menjaga dan hubungannya dengan manusia lain demi tercapainya hubungan yang harmonis, tapi manusia itu harus menyadari dan menjaga dengan Allah Yang $\mathrm{M}$ aha Segalanya.

Konsep ESQ menurut Ary Ginanjar melalui pengembangan EQ dan SQ sebagai berikut:

a. Kecerdasan Emosional (EQ)

Kecerdasan emosional ini harus melihat kepada aspek hati sebagai radar dalam hidup manusia dalam melangkah di kehidupan.

Kemampuan melihat sesuatu secara jernih dan objektif harus di dahului oleh kemampuan mengenali faktor-faktor yang mempengaruhinya. Caranya dengan mengembalikan manusia pada hati yang suci atau suara hati. Karena menurut Ary Ginanjar kecerdasan emosi meliputi unsur suara hati, kecerdasan diri, motivasi, etos kerja, keyakinan, integritas, komitmen, kinsistensi, presistensi, kejujuran, daya tahan dan keterbukaan.

Enam tablet pereda emosi menurut Ary Ginanjar, antara lain :

1 Marah, ucapkan Istigfar, A stagfirulloh.

2. Kehilangan dan sedih, ucapkan Innalillaahi wa inna ilaihi raa'jiuun.

3. Bahagia, ucapkan Alhamdulillah. 
4. Kagum, ucapkan SubhanA llah.

5. Takut, ucapkan Allahu A kbar.

6. Panik, ucapkan Laa hawlaa walaa quwwaata illa billah. (Ary Ginanjar, 2003: 228)

b. Kecerdasan Spiritual (SQ)

M enurut Ary Ginanjar bahwa di dalam ESQ kecerdasan spiritual adalah kemauan untuk memberi makna ibadah terhadap setiap prilaku dan kegiatan melalui langkah-langkah dab pikiran yang bersifat fitrah atau kembali suci menju manusia yang seutuhnya dan memiliki pemikiran tauhid yang haqiqi. Dengan demikian kecerdasan spiritual haruslah disandarkan kepada Allah SWT dalam menjalankan segala aktivitas kehidupan untuk mendapatkan jiwa yang fitrah dan haqiqi.

Kecerdasan spiritual harus seimbang dengan kecerdasan emosional agar manusia tersebut tidak mementingkan salah satunya. Karena, orang hidup di dunia harus bisa mencukupi kebutuhannya semasa dia hidup di dunia dan mempunyai bekal untuk hidup di akhirat nanti. M elalui sholat tahajud yang dikerjakan secara rutin kecerdasan spiritual seseorang bisa meningkat secara pesat dan secara tidak sadar kecerdasan emosionalnya pun mampu meningkat.

Dalam

proses

mengembangkan ESQ diperlukan langkah-langkah yang tepat agar dalam prosesnya nanti bisa lancar dan maksimal, Ary Ginanjar dalam bukunya memberikan langkahlangkah dalam upaya mengembangkan ESQ sebagai berikut:

C. ESQ dalam M anusia Sempurna

Menurut Ary Ginanjar seorang manusia yang ingin menjadi pribadi yang sempurna dengan melakukan enam asas pembangun mental. Enam asas ini merupakan pemaknaan dari rukun iman yang berjumlah enam. Enam asas pembangun mental yang mengacu pada rukun iman antara lain :

a) Iman kepada Allah SW T

Manusia harus mempunyai rasa yang sangat kuat pada dirinya dan yaqin bahwa Allah SW T sebagai Dzat Yang Maha Segala-galanya. Dalam kehidupan kesehari-harinya manusia harus selalau mengingat dan yaqin bahwa Allah yang 
menentukan jalan kehidupannya dan selalu mensyukuri apa yang telah di berikan oleh Allah SW T. Hal ini jika setiapmanusia merasakan dan memahaminya manusia itu kan menjadi pribadi yang sabar, tawakal dan istiqomah.

Seorang manusia yang sudah memiliki dan menumbuhkan rasa keimanan yang kuat kepada Allah SW T melaui pembelajaran yang panjang mulai dari mengetahui sifatsifat wajib dan sifat mukhal Allah. Orang itu dalam dirinya akan timbul Iman yang kuat kepada Allah mengetahui karena semua yang ada di seluruh alam semesta ini adalah ciptaan Allah.

Jika dalam diri orang tersebut sudah tertanam iaman yang kuat maka orang itu akan lebih jauh mengenal dirinya mampu memotivasi dirinya sehingga orang tersebut akan dekat Allah SW T.

b) Iman kepada $M$ alikat

$M$ alaikat adalah hamba Allah yang paling taat karena, setiap Allah memberikan perintah kepada $M$ alikat-malaikatN ya mereka dengan sangat patuh menjalakannya. Begitu pula dengan manusia sebagai hamba Allah yang mempunyai keistimewaan ketika mereka mempunyai komitemen seperti seorang malaikat yang selalu taat dalam menjalankan semua perintah dan larangan Allah SW T mereka akan menjadi manusia yang sempurna.

c) Iman kepada Rosul Allah Rosul sebagai utusan Allah untuk menyampaikan semua ajaran yang diberikan oleh Allah dan mempunyai sifat-sifat yang bagus dan sebagai seorang pemimpin yang arif bijaksana bagi kaum-kaumnya. Hendaklah seseorang mencotoh surry tauladan para Rosul agar dalam menjalani kehidupan di cintai dan di sayangi semua orang.

d) Iman kepada Kitab Allah

Allah menurunkan kitab- $\mathrm{N}$ ya kepada para $\mathrm{Nabi}$ agar memiliki pedoman yang kuat dan berpegang teguh hanya kepada Allah. Hal ini secara tidak langsung Allah menyuruh kepada semua hambanya agar selalau belajar bisa membedakan mana yang baik dan mana yang buruk. Sehingga dalam hati dan tubuh manusia tertanam dan mempunyai rasa iman yang kuat. e) Iman kepadaHari Akhir 
Dalam hal ini, manusia agar selalu berorientasi kepada tujuan akhir dalam setiap langkah yang dibuat. Melakukan setiap langkah kehidupan dan menjalaninya secara optimal dan sungguh-sungguh, memiliki kendali diri dan sosial karena memiliki keyaqinan akan ad anya hari kemudian.

f) Iman kepada Q adha dan Q adar

Manusia agar memiliki hasil dari prinsip keyaqinan, kesadaran dan kesabaran dalam berusaha pengetahuan akan kepastian hukum sosial, memahami akan pentingnya sebuah proses yang harus dilalui dan meliki kesadaraan akan ketetapan yang sudah dibuat oleh Allah SW T.

Keenam asas itu disusun secara sistematis sehingga saling menopang antara stu sama lain. Semuanya bergerak, berthowaf, mengelilingi titil Tuhan. Artinya, keenam asas itu berpusat atau berkiblat kepada kehendak Allah. Disinal manusia memiliki nilai satu, hati yang satu, hati yang ihsan pada pusat orbit (God Spot). (Ary Ginanjar, 2003: 104) Keenam asas itu merupakan pondasi yang kokoh dalam membangun ESQ yang kuat dalam diri manusia. d. ESQ dalam pembentukan Pribadi dan Sosial

ESQ dalam proses pembentukan pribadi dan sosial memiliki prinsip-prinsip dalam pembentukannya mengacu pada rukun islam, antara lain :

a) Syahadat

ESQ dalam pembentukan ketangguhan pribadi seseorang merupakan penjabaran makna syahadat dalam rukum islam. Syahadat adalah sebuah keyakinan bahwa tiada Tuhan selain Allah SW T, dalam membangun ketangguhan pribadi seseorang akan keyakinannya yang begitu besar akan menciptakan sebuah dorongan dalam upaya mencapai suatu tujuan, syahadat akan membangkitkan suatu keberanian dan optimisme sekaligus ketenangan batiniah dalam menjalankan hidup karena Allah selalu menyertainya dalam setiap langkah kehidupan.

Syahadat merupakan sebuah usaha yang dimulai dengan tujuan akhir dengan membulatkan tekad diriri. Keyakinan bersyahadat itu telah ditanamkan kuat-kuat dalam hati, maka keyakinan itu akan berubah bentuk menjadi sebuah 
energi dasyat yang mendorong jiwa manusia bergerak mencapai citacitanya. Dorongan energo itu selanjutnya akan melahirkan upaya kongkret untuk mewujudkan visi tersebut. Perwujudan berupa upaya ini merupakan turunan dari kekuatan iman melalui dorongan syahadat. (Ary Ginanjar Agustin, 2001: 267)

b) Sholat

$$
\text { Dalam pembentukan }
$$

karakter seseorang mengacu pada makna penjabaran sholat. Sholat adalah suatu metode yang dilakukan seorang hamba dalam menyampaikan rasa taat, syukur, bernunajat dan memanjatkan do'a kepada sang M aha Pencipta. Sholat adalah suatu metode relaksasi untuk menjaga kesadaran diri agar tetap memiliki cara berfikir yang suci, sholat juga suatu langkah untuk membangun kekuatan positif dalam diri, sholat juga sebuah metode yang dapat meningkatkan dan mengembangkan kecerdasan emosional dan spiritual secara terus menerus. Agar terbentuknya sebuah karakter yang seimbang antara kecerdasan emosi dan spiritual. ( Ary Ginanjar Agustin, , 2001: 282)
Fungsi shalat dalam ESQ adalah sebagai mekanisme untuk mengingat sifat-sifat mulia yang dimiliki oleh sang pencipta jiwa manusia. Ketika, sholat manusia diminta untuk melafadzkan sifatsifat agung yang dimiliki-Nya dengan sepenuh jiwa, serta memuji asma-N ya secara berulang-ulang. ( Ary G inanjar, 2003: 279)

Dalam pelaksanaan sholat tahajud yang dikerjakan pada malam hari, seseorang yang melaksanakannya akan mempunyai waktu yang sangat istimewa waktu yang hanya digunakan untuk bermunajat kepada Allah, yang mampu memberikan ketenangan dalam jiwanya sehingga orang itu mampu lebih memahami dirinya dan mengenal lebih dalam kepada sang Pencipta-N ya.

Oleh karena itu, sholat tahajud sebagai wujud mengenal dan memahami lebih jauh dirinya yang nantinya guna untuk berhungan dengan sesama manusia dan juga untuk lebih memahami dirinya untuk bisa mengenal dan berhubungan dengan Allah. Dengan dimikian sholat tahajud dapat menjaga dan menyeimbangkan 


\section{TKaKa \\ Jurnal Komunikasi dan Konseling Islam \\ Volume I, Nomor 1, Januari 2021}

antara emosional dan spiritual seseorang.

Ari Ginanjar mengatakan fungsi relaksasi pada sholat akan memberikan ruang berfikir bagi perasaan intuintif, sekaligus menstabilkan kecerdasan emosi serta spiritual seseorang dan menjaga kefitrahan suara hati (The God Spot). (Ary Ginanjar Agustin, 2001: 283)

C) Puasa

Puasa adalah sebuah wujud pengendalian diri dalam menahan hawa nafsu dalam diri. Selain untuk menahan hawa nafsu puasa juga merupakan suatu metode dalam pengendalian hati agar bisa menyeimbangkan antara emosional dan spiritual dalam setiap diri.

Pada dasarnya seseorang yang ditutupi oleh nafsu mereka akan lupa akan segalanya mereka akan lebih mementingkan dirinya. Yang lebih parah jika orang tersebut sudah dikendalikan oleh nafsunya, orang itu akan melupakan siapa sejatinya yang menciptakan dia, siapa yang memberikan semua fasilitas dalam hidupnya. Oleh karena itu puasa adalah metode yang sangat kuat dalam upaya pengendalain nafsu (emosi) seseorang sehingga orang tersebut bisa menjaga nafsunya.

d) Zakat

Zakat merupakan memberikan sebagian harta kita kepada orang lain yang membutuhkan hal ini adalah sebuah perwujutan agar kita menjadikan pribadi yang dermawan dan memberi rizki kepada orang lain. Peran zakat dalam kehidupan sosial sangatlah berarti supaya kita bisa lebih perhatian, toleran, empati, menolong dan sifat sosial yang tinggi. Karena, kita sebagai manusia adalah makhluk sosial yang tidak dapat hidup sendiri.

e) $\mathrm{Haji}$

Haji dalam pembentukan ESQ adalah suatu ibadah yang sangat khusus bagi mereka yang mampu dalam artian mampu dari segi fisik, psikis dam matrial. Setiap rukun-rukun haji akan mengantarkan seseorang lebih sangat dalam pembentukan emosial dan spiritualnya.

Ibadah haji yang khusus yang dilak sanakan pada waktu yang khusus seseorang akan dihadapkan dengan orang-orang yang beraneka ragam mulai dari fisik, karakter dan 
lain sebagainya. Dengan demikian orang yang melaksanakan ibadah haji harus mampu menjaga emosialnya dan tetap dengan tujuannya yaitu beribadah kepada Allah.

Kelima prinsip ini merupakan langkah selanjutnya setelah memiliki pondasi yang kokoh. Sholat tahajud merupakan metode yang sangat pas dalam pengevaluasian diri seseorang, untuk merenungi segala sesuatu yang sudah diperbuat dan mengadukannya kepada Allah guna untuk meminta diberikan bantuan agar menjadi manusia yang baik dengan tetap pada satu tujuan diciptakannya manusia.

\section{M etode Penelitian}

Penelitian yang berjudul "Pengaruh Salat Tajahud Terhadap Emotional Spiritual Quotient (ESQ) Santri Putra Asrama Al-Hikmah Pondok Pesantren Darussalam Blokagung Banyuwangi" termasuk kategori penelitian kuantitatif.

Pada penelitian ini menggunakan pedekatan kuantitatif yang merupakan metode penelitian yang berlandaskan pada filsafat positivisme, digunakan untuk meneliti pada popu;asii atau sampel tertentu, pengumpulan data menggunakan instrumen penelitian, analisis data bersifat kuantitatif atau statistik dengan tujuan untuk menguji hipotesis yang telah ditetapkan. ( Sugiono, 2016: 8)

Berikut langkah-langkah penelitian kuantitatif:

a. M embuat Rumusan M asalah Setiap penelitian harus bersumber dari adanya masalah. Setelah selesai langkah mengidentifikasi dan membatasi masalah selanjutnya, peneliti membuat rumusan masalah dan rumusan masalah ditulis dengan menggunakan kalimat Tanya.

b. M enentukan Landasan Teori Langkah selanjutnya mencari jawaban dari masalah yang sudah dirumuskan. Jawaban tersebut diperoleh dari hasil pencarian terhadap teori-teori yang sudah relevan.

c. M erumuskan Hipotesis Jawaban sementara dalam penelitian kuantitatif disebut dengan hipotesis. Dan hipotesis dirumuskan dengan cara membaca dan mencari teori-teori yang sesuai 
dengan solusi dari rumusan masalah dalam penelitian tersebut.

d. M elakukan Pengumpulan Data Pada tahap ini sebelum melakukan pengumpulan data. Peneliti harus terlebih dahulu membuat instrument penelitian berupa kuesioner, test, lembar observasi dan menguji validitas dan rebilitas instrumen tersebut. Dalam hal pengumpulan data dalam penelitian kuantitatif dapat berupa angka atau data deskriptif yang dikuantitatifkan.

e. M elakukan Analisis Data

Analisis data dilakukan untuk menguji hipotesis yang sudah dibuat. Dalam analis data yang dilakukan dalam penelitian kuantitatif adalah statistik. Data analisis tersebut disajik an dan diberi pembahasan dalam setiap babnya masing-masing. Penyajian data dapat menggunakan grafik, diagram dan tabel.

f. M enyimpulkan

M enyimpulkan adalah langkah terakhir dari penelitian kuantitatif. Kesimpulan merupakan hasil dari pengujian hipotesis apakah diterima atau ditolak. Kesimpulan ditulis dengan singkat, padat dan jelas. (Sugiono, 20 16: 50.)

Menentukan Populasi dan Sampel

a) Populasi

Populasi adalah keseluruhan subyek penelitian, apabila seseorang ingin meneliti elemen yang ada dalam wilayah penelitian, maka penelitiannya merupakan penelitian populasi. Studi atau penelitiannya juga disebut studi populasi atau studi sensus, sebagaimana disebutkan dalam Encyclopedia of Educational Evalution: A populasi is aset (or collection) of all elements possessing one or more attributes of interst. (Suharsimi Arikunto, 2016:117)

Populasi adalah wilayah generalisasi yang terdiri atas: obyek atau subyek yang mempunyai kualitas dan karakteristik tertentu yang ditetapkan oleh peneliti untuk dipelajari dan kemudian ditarik kesimpulannya. ( Sugiono, 2012: 61)

Dalam penelitian ini yang dijadikan populasi adalah santri asrama Al-Hikmah Pondok Pesantren Darussalam Blokagung 
Banyuwangi yang masih aktif di asrama.

b) Sampel

Sampel adalah bagian dari jumlah dan karakterisik yang dimiliki oleh populasi. 'Sugiono, 2012: 6)

Dengan demikian sampel adalah sebagian dari populasi yang karateristiknya sudah ditetapkan dan hendak diteliti, dan bisa mewakili keseluruhan populasinya sehingga jumlahnya lebih sedikit dari populasi.

Teknik pengambilan sample yang akan digunakan peneliti adalah probability sampling yang berjenis simple random sampling. Probability sampling adalah teknik pengambilan sampel yang memberikan peluang yang sama bagi setiap unsur (anggota) populasi untuk dipilih menjadi anggota sampel. ('Sugiono, 2012: 6)

(Sedangkan simple random sampling dikatak an simple (sederhana) karena pengambilan anggota sampel dari populasi dilakukan secara acak tanpa memperhatikan strata yang ada dalam populasi itu. 'Sugiono, 2012: 6)
Jumlah populasi dalam penelitian ini adalah seliruh santri asrama al-hikmah yang masih aktif di asrama al-hikmah. M engingat jumlah populasi santri asrama alhikmah cukup besar yang berjumlah 300 santri maka, untuk menghemat biaya, tenaga dan waktu. Dalam penelitian ini peneliti mempersempit populasi yaitu seluruh santri asrama al-hikmah yang masih aktif di asrama dengan menghitung ukuran sample yang dilakukan dengan menggunakan teknik Slovin. (Sugiono, 2012: 87)

Adapun penelitian ini menggunakan rumus Slovin karena dalam penarikan sampel, jumlahnya harus representative agar hasil penelitian dapat digeneralisasikan dan perhitungannya pun tidak memerlukan tabel jumlah sampel, namun dapat dilakukan dengan rumus dan perhitungan sederhana.

$$
\text { Rumus Slovin untuk }
$$
menentukan sampel adalah sebagai berikut:

$$
\begin{gathered}
\mathrm{n}=\frac{\mathrm{N}}{1+\mathrm{N}(\mathbf{e})^{2}} \\
\text { Keterangan : } \\
\mathrm{n}=\text { Ukuran sampel/jumlah } \\
\text { responden }
\end{gathered}
$$




$$
\mathrm{N}=\text { U kuran Populasi }
$$

$E=$ Presentase kelonggaran ketelitian kesalahan pengambilan sampel yang masih bisa ditolerir, $e=0,1$

Dalam rumus Slovin ada ketentuan sebagai berikut :

Nilai e $=0,1(10 \%)$ untuk populasi dalam jumlah besar

Nilai e =’ $0,2(20 \%)$ untuk populasi dalam jumlah kecil

Jadi rentang sampel yang dapat diambil dari teknik Solvin adalah $10-20 \%$ dari populasi penelitian.

$$
\text { Jumlah populasi dalam }
$$

penelitian ini adalah sebanyak 300 santri, sehingga presentase kelonggaran yang digunakan adalah $10 \%$. Maka untuk mengetahui sampel penelitian, dengan perhitungan sebagai berikut:

$$
\begin{aligned}
& n=\frac{N}{1+N(e)^{2}} \\
& \pi=\frac{300}{1+300(0,1)^{2}} \\
& n=\frac{300}{4} \\
& n=75
\end{aligned}
$$

Berdasarkan perhitungan diatas sampel yang menjadi responden dalam penelitian ini sebanyak 75 santri yang masih aktif di asrama Al-Hikmah Pondok Pesantren Darussalam Blok agung Banyuwangi.

Pada dasarnya kegiatan penelitian adalah serangkain kegiatan untuk mengukur sebuah fenomena sosial atau alam, meneliti dengan menggunakan data yang ada. $\mathrm{H}$ al ini disebabkan prinsip penelitian adalah mengerjakan pengukuran. $M$ aka harus tersedia alat ukur yang baik. Dalam penelitian, alat ukur juga disebut juga dengan instrumen penelitian.

$$
\text { Jadi, Instrumen }
$$
penelitian adalah suatu alat yang dipakai untuk mengukur fenomena alam ataupun sosial yang diamati. Secara spesifik semua fenomena tersebut disebut dengan variabel penelitian. (Sugiono, 2016,:148.)

82 | | Pengaruh Sholat Tahajud T erhadap E SQ (E motional Spiritual Q uotient) Santri $\mathrm{N}$ ur H afiah, M uchammad Saiful M achfud penelitian tergantung pada jumlah variabel penelitian yang telah ditetapkan untuk diteliti. Dalam penelitian yang berjudul "Pengaruh Sholat Tahajud 
Terhadap ESQ (Emosional Spiritual Quetiont) Santri Putra asrama AlHikmah" peneliti menggunakan angket (kuesioner) dalam penelitian ini. Maka, ada dua instrumen yang harus dibuat, yaitu :

1. Instrumen untuk mengukur Sholat Tahajud (variabel X)

2. Instrumen untuk mengukur ESQ santri (variabel Y)

Dalam hal ini, kuesioner yang digunakan oleh peneliti adalah kuesioner tertutup. Yakni seluruh jawaban dari pernyataan setiap item-itemnya dalam kuesioner sudah disediakan oleh peneliti sehingga responden cukup dengan memberikan tanda checklist $(\checkmark)$ pada salah salah satu alternative jawaban yang sudah disediakan.

Sedangkan untuk keperluan analisis kuantitatif, maka jawaban tersebut dapat diberi skor menggunakan skala likert.Skala likert digunakan untuk mengukur sikap, pendapat, dan persepsi seseorang atau sekelompok tentang kejadian atau gejala sosial. (Ridwan dan Sunarto. H, 2015: 20-21)

Pada skala likert aspek variabel dijadikan sebagai tolak ukur penyusunan item instrument Setiap individu memiliki jawaban yang berbedabeda, tidak ada jawaban yang dianggap benar atau salah. Pada skala penelitian ini digunakan empat pilihan jawaban, yaitu sangat setuju (SS), setuju (S), tidak setuju (TS) dan sangat tidak setuju (STS). Tidak dimasukannya pilihan netral atau cukup setuju. Karena dikhawatirkan ada kecenderungan responden akan memilih jawaban netral atau cukup setuju, sehingga tidak ada perbedaan variabel jawaban dari setiap item.

Untuk memperoleh informasi dan data yang relevan, maka dalam penelitian ini peneliti menggunakan beberapa teknik penggumpulan data, sebagai berikut :

a) W awancara (Interview)

W awancara atau interview adalah percakapan yang 
dilakukan dengan cara bertatap muka secara langsung mengajukan pertannyaan dan dijawab secara lisan oleh narasumber dengan tujuan untuk memperoleh informasi.

\section{b) Observasi}

Observasi adalah suatu teknik atau cara mengumpulkan data dengan mengamati dan mencatat sistematika fenomena terhadap kegiatan yang sedang berlangsung di lapangan.

c) Dokumentasi

Dalam penelitian ini dokumentasi berupa berkas asrama Al-Hikmah, database asrama Al-Hikmah, angket yang sudah di isi oleh responden, foto dan sumber lain baik dari teoriteori, buku dan karya ilmiyah yang berhubungan dengan penelitian.

d) Angket

Angket atau questionnare adalah suatu teknik atau cara pengumpulan data secara tidak langsung (peneliti langsung bertanya jawab dengan responden). Metode ini berupa angket yang berisi pertanyaanpertanyaan yang harus dijawab oleh responden terkait dengan pengaruh sholat tahajud terhad ESQ (emotional spiritual quotient) Santri Putra Asrama Al-Hikmah Pondok Pesantren Darussalam Blok agung Banyu wangi.

Teknik analis data dalam penelitian kuantitatif menggunakan statistik. Terdapat dua macam statistik untuk menganalisis data dalam penelitian, yaitu statistik deskriptif dan statistik inferensial. Statistik inferensial merupakan statistik parametris dan nonparametris. (Sugiono, 2016: 207) Dalam penelitian ini menggunakan statistik inferensial.

Penggunaan statistik parametris dan non parametris tergantung pada penemuan asumsi dan jenis data yang akan ditulis. Pada statistik parametris memerlukan terpenuhinya asumsi, yakni data yang akan dianalisis harus berdistribusi normal. Selanjutnya dalam penggunaan salah satu tes 
mengharuskan data dua kelompok atau lebih yang harus homogen. Dalam regresi harus terpenuhi asumsi linearitas. (Sugiono, 2016: 207)

$\begin{array}{crr} & \text { Regresi atau peramalan } \\ \text { adalah } & \text { suatu } & \text { proses }\end{array}$ memperkirakan secara sistematis tentang apa yang paling mungkin terjadi di masa yang akan datang berdasarkan informasi masa lalu dan sekarang yang memiliki agar kesalahannya dapay diperkecil. Kegunaan regresi dalam penelitian salah satunya adalah untuk meramalkan atau memprediksi variabel terikat (Y) apabila variabel bebas (X) diketahui. Regresi sederhana dapat dianalisi karena didasari oleh hubungan fungsional atau hubungan sebab akibat (kasual) variabel bebas $(X)$ terhadap variabel terikat $(Y)$. (Ridwan dan Sunarto. 2018: 96)

\section{Persamaan regresi}

dirumuskan: $Y=a+b X$ Dimana :

$Y=$ (dibaca $Y$ topi) subjek variabel terikat yang diproyeksikan

$$
\begin{aligned}
& X \text { = Variabel bebas yang } \\
& \mathrm{a}=\mathrm{N} \text { ilai kontanta harga } \mathrm{Y} \\
& \text { jika } X=0 \\
& \text { b = Nilai arah sebagai } \\
& \text { penentu ramalan } \\
& \text { (prediksi) yang } \\
& \text { menunjukkan nilai } \\
& \text { peningkatan }(+) \text { atau } \\
& \text { nilai penurunan (-) } \\
& \text { variabel } Y \\
& \text { b } \quad=\frac{y-E X Z Y}{\frac{2}{2}-\left(\sum X\right)^{2}} \\
& a \stackrel{5.2 x}{=}
\end{aligned}
$$

Langkah-langkah

menjawab Regresi Sederhana:

1. Membuat $\mathrm{Ha}$ dan $\mathrm{Ho}$ dalam bentuk kalimat.

$\mathrm{Ha}$ : Terdapat pengaruh yang signifikan antara sholat tahajud terhadap ESQ (Emosional Spiritual Quotien) santri putra asrama Al-Hikmah Pondok Pesantren Darussalam Blokagung Banyuwangi. 


\section{$\mathrm{KaKa}$ \\ Jurnal Komunikasi dan Konseling Islam \\ Volume I, Nomor 1, Januari 2021}

Ho : Tidak terdapat pengaruh

yang signifikan antara

sholat tahajud terhadap

ESQ (Emosional Spiritual

Quotien) santri putra

asrama Al-Hikmah

Pondok Pesantren

Darussalam Blokagung

Banyuwangi.

2. Membuat $\mathrm{Ha}$ dan $\mathrm{HO}$ dalam bentuk statistik.

$$
\begin{aligned}
& \mathrm{Ha}: r \neq 0 \\
& \mathrm{Ho}: r=0
\end{aligned}
$$

3. Membuat tabel penolong untuk menghitung angka statistik.

4. Memasaukkan angka-angka statistik dari tabel penolong dengan rumus:

1) $M$ enghitung rumus $b$

$$
\begin{aligned}
& \mathrm{b}=\frac{\mathrm{n} \Sigma x y-\sum \Sigma \sum Y}{\mathrm{n} \Sigma x^{2}-\left(\sum x\right)^{2}}= \\
& \frac{75 .(79991)-(2415)(79991)}{75.79117)-(2415)^{2}}= \\
& \frac{5410005}{100050}=49,6
\end{aligned}
$$

2) M enghitung rumus a

$$
\begin{aligned}
& a=\frac{\sum Y-\bar{b}, \Sigma X}{n}=\frac{2464-496(2415)}{7}= \\
& \frac{117220}{75}=1564,26
\end{aligned}
$$

5. Mencari jumlah kuadrat regresi $\left(/ K_{\text {Reg }[a]}\right) \quad$ dengan rumus:

$$
\begin{aligned}
& \not \mathrm{K}_{\text {Reg }[\mathrm{al}]}=\frac{\left(2 r_{3}^{2}\right.}{n}= \\
& \frac{(2464)^{2}}{75}=\frac{0.71296}{75}= \\
& 80950,6
\end{aligned}
$$

6. Mencari jumlah kuadrat regresi $\left(j K_{\operatorname{Reg}(b \mid a)}\right)$ dengan rumus:

$$
\begin{aligned}
& J \mathrm{~K}_{\text {Re } g(b \mid a)}= \\
& \text { b. }\left\{\sum X N-\frac{\sum X X(\Sigma n)}{n}\right\} \\
& =49,6
\end{aligned}
$$

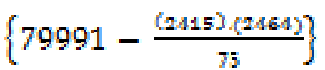

$$
\begin{aligned}
& =32249,92
\end{aligned}
$$

7. Mencari jumlah kuadrat redusi $\left(/ \kappa_{\tilde{R} g}\right)$ dengan rumus:

$$
\begin{aligned}
& J K_{\operatorname{mas}} \\
& = \\
& \sum Y^{2}-j K_{\text {Re g }}(6 \mid a)-j K_{\text {Rag }[a]} \\
& =81960-32249,92 \\
& -80950,6= \\
& 31240,52
\end{aligned}
$$

8. Mencari rata-rata jumlah kuadrat regresi $\left(R K_{\operatorname{Res}[a 1}\right)$ dengan rumus:

$$
\begin{aligned}
& \mathrm{R}\left[\mathrm{K}_{\text {Res [a] }}=j \mathrm{~K}_{\text {Res }: a]}=\right. \\
& 80950,6
\end{aligned}
$$

9. Mencari rata-rata jumlah kuadrat regresi $\left(R / K_{\text {Rag }(b] a)}\right)$ dengan rumus:

\section{$\mathrm{R}$}

$$
\gamma \mathrm{K}_{\text {Rag } b] \mathrm{a}}=J \mathrm{~K}_{\text {Reg }(b] \mathrm{a})}=
$$

32249,92 


\section{$\mathrm{KaKa}$ \\ Jurnal Komunikasi dan Konseling Islam \\ Volume I, Nomor 1, Januari 2021}

10. Mencari rata-rata jumlah

kuadrat residu $\left(R / K_{\operatorname{Ras}}\right)$

dengan rumus:

$$
\begin{gathered}
\mathrm{R} / \mathrm{K}_{\text {Res }}=\frac{j K_{\text {REs }}}{n-2}= \\
\frac{31240,52}{75-2}=427,95
\end{gathered}
$$

11. Menguji signifikansi dengan rumus:

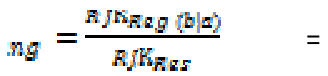

$$
\begin{aligned}
& \frac{1,92}{95}=75,35
\end{aligned}
$$

$$
\text { Kaidah pengujian }
$$

signifikansi :

Jika $F_{\text {hitung }} \geq F_{\text {tabel. }}$ maka tolak Ho artinya signifikan dan $F_{\text {hitung }} \leq F_{\text {rabal }}$ terima Ho artinya tidak signifikan

Dengan taraf signifikan : $\alpha=0.01$ atau $\alpha=0.05$

$$
\text { Carilah nilai } F_{\text {tabel }}
$$

menggunakan tabel Fdengan rumus :

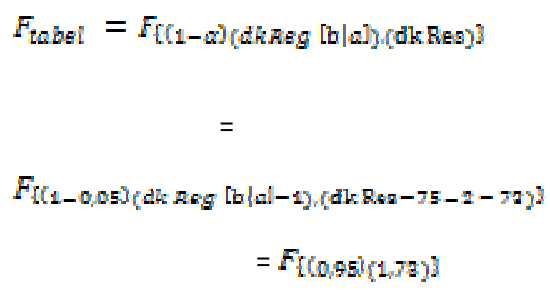

Cara mencari $n$ : angka $73=$ penyebut

$$
F_{\text {tabel }}=3,97
$$

$$
\text { Ternyata }{ }_{n g}>F_{\text {tabsel }}
$$

maka tolak Ho artinya signifikan.

12. M embuat kesimpulan

$$
\text { Karena ing }=75,35
$$

lebih besar dari $:=3,9 \%$ maka menolak $\mathrm{Ho}$ dan menerima $\mathrm{Ha}$. Dengan demikian terdapat pengaruh yang signifikan antara sholat tahajud terhadap ESQ (Emosional Spiritual Quotient) santri putra asrama Al-H ikmah Pondok Pesantren Darussalam Blokagung Banyuwangi.

\section{KESIMPULAN}

Berdasarkan hasil penelitian dan analisis data tentang pengaruh sholat tahajud terhadap ESQ (Emosional Spiritual Quotient) santri putra asrama Al-Hikmah Pondok Pesantren Darussalam Blokagung Banyuwangi. Maka dari rumusan masalah dan hipotesis yang telah diajukan. Peneliti dapat menarik kesimpulan sebagai berikut

angk a 1 =pembilang 
Berdasarkan hasil angket dan analisis data statistik menggunakan metode regresi sederhana diketahui $F_{\text {hitung }}=75,35$ lebih besar dari $F_{\text {tabsl }}=3,97$ sehingga menerima $\mathrm{Ha}$ dan menolak $\mathrm{Ho}$. Artinya "Terdapat pengaruh yang singnifikan antara sholat tahajud terhadap ESQ (Emosional Spiritual Quotient) santri putra asrama AlHikmah Pondok Pesantren Darussalam Blokagung Banyu wangi".

\section{DAFTAR PUSTAKA}

Al Barry Dahlan. M. (2001). Kamus IImiah Populer. Surabaya: Arkola.

Ary Ginanjar Agustin. (2003). ESQ PowerSebuah I nner J ounery M elalui Al-I hsan. J akarta: Arga.

Ary Ginanjar Agustin. (2001) .Rahasia Sukses Membangun Kecerdasan Emosi \& Spiritual ESQ. Jakarta: Agra, 2001

Herliawan Setiabudi.(2016).Amalan Sunnah Pemborong Pahala. Solo : Pustaka Arafah.

Moh. Sholeh. (2012). Terapi Shalat Tahajud. Jakarta: Mizan Publika.

Muhammad Bin Ismail Al Bukhori. (2014) Shohih Bukhori. Lebanon : Darrul Fikher. Juz 1
Muhammad Khatib. (2013).Tangisan $M$ alammu $D$ apat $M$ engubah Takdir. Jak arta: M itrapress.

Nanang M artomo.(2016). M etode Penelitian Kuantitatif. Jakarta: RajaG rafindo Persada.

Ridwan dan Sunarto. $H$. (2015).Pengantar Statistik untuk Penelitian: Pendidikan, Sosial, Bisnis, K omunikasi, Ekonomi dan Bisnis. Bandung: Alfabeta.

Samsul Munir Amin. (2010).Bimbingan dan K onseling I slam. J ak arta: Amzah, 2010.

Saiful Akhyar Lubis. (2007).K onseling Islam : kyai \& pesantren. Yogyakarta: Elsaq Press.

Sayyid Bakri Syatha. (2017).I'anah Ath Thalibi.Lebanon : DKI, Juz. 1.

Sheikh Zaynuddin AI M alibari.

(2017) Fathul M u'in. Lebanon : DKI.

Sobron Zayyan. (2011).D ahsyatnya Sholat Fardhu dan Sunah. Bandung: Kawan Pustaka, 2011 Samsul Munir Amin. (2010) Bimbingan dan Konseling Islam. Jakarta: Amzah, 2010.

Sugiyono. (2014). Metode Penelitian Administrasi. Bandung: Alfabeta.

Sugiono.(2016).Metode Penelitian $K$ uantitatif, Kualitatif, dan $R \& D$. Bandung: Alfabeta.

Suharsimi Arikunto.(2016). Prosedur Penelitian Suatu Pendekatan Praktik. Jakarta: Ribeka Cipta.

Tim Penyusun Buku Dokumen Asrama. (2018). Dokumen A srama A I H IK mah. Banyu wangi.

Tim Penyusun Buku Pedoman Skripsi Fakultas Dakwah dan Komunikasi Islam. (2019). Panduan Skripsi Fakultas Dakwah dan Komunikasi Islam. Banyuwangi. 


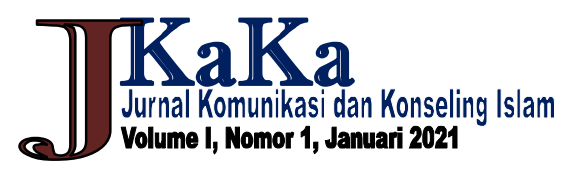

Tim Penyusun Buku Dokumen Asrama. (2018). Dokumen A srama AI HIK mah. Banyu wangi.

Tim Penyusun PSPDB. (2019). PAPDB (Penerimaan Santri dan Peserta D idik Baru). Banyuwangi.

Utsman Al Khoubawy. (2010).

D urrotun N asihin. Lebanon : DKI. 